\title{
Karakteristik Telur Berdasarkan Umur Ayam dan Ransum yang Diberikan
}

\section{The Eggs' Properties Based on Layers' Age and Feed Types}

\author{
Abbas*, Muh Basir Paly, Rifaid \\ Jurusan Ilmu Peternakan, Fakultas Sains Dan Teknologi \\ Universitas Islam Negeri Alauddin Makassar
}

\author{
Article history \\ Received: Aug 30, 2020; \\ Accepted: Feb 23, 2021 \\ * Corresponding author: \\ E-mail: \\ adolf_scfm@yahoo.co.uk \\ DOI: \\ 10.46549/jipvet.v11i1.145
}

\section{(c) (1) (D)}

\begin{abstract}
This study aimed to observe the properties of eggs produced based on laying age and different feed compositions. This research was conducted in September 2017 at Cahaya Mario Group Farm, Puncak Mario, Sidenreng Rappang Regency, South Sulawesi. The materials used in this research were; 45 Lohman-strain layers, a digital scale with $0,001 \mathrm{~g}$ sensitivity, calipers, needle scales with $0,1 \mathrm{~g}$ sensitivity, buckets, feedlots, water containers, plastic bags, plates, and cleaning tools. Randomized Block Design was applied in this work which consisted of 3 different feed types and 3 different age groups of layers with 3 replications. The parameters measured in this study consisted of the egg's exterior and interior qualities. Based on statistical analysis, feed types and age groups showed no significant effect on the external quality of the eggs namely the egg's shell thickness as well as no significant effect on eggs weight. The egg's shell thickness varied from 0.42 to $0.44 \mathrm{~mm}$. Interior quality, especially yolk color, was significantly influenced by age groups. The egg's viscosity was significantly influenced by different feed types.
\end{abstract}

Keywords: Egg properties; Egg viscosity; Yolk color; Lohman-strain; Layer.

\section{Abstrak}

Penelitian ini bermaksud untuk mengobservasi karakteristik telur berdasarkan umur ayam dan perbedaan komposisi ransum yang diberikan. Penelitian ini dilakukan di bulan Agustus hingga September 2017 bertempat di Farm Cahaya Mario Group, Puncak Mario, Kabupaten Sidenreng Rappang, Sulawesi Selatan. Materi yang digunakan dalam penelitian ini yaitu : ayam Lohman sebanyak 45 ekor, timbangan digital dengan kepekaan 0,001 g, jangka sorong, timbangan jarum dengan kepekaan $0,1 \mathrm{~g}$, ember, tempat ransum, tempat minum, plastik, piring dan alat kebersihan. Tiga (3) jenis ransum diberikan pada tiga (3) kelompok umumr ayam yang berbeda dengan replikasi sebanyak tiga (3) kali, menggunakan Rancangan Acak Kelompok (RAK). Parameter yang diukur pada penelitian ini terdiri dari kualitas eksternal telur, dan kualitas interior telur. Berdasarkan hasil analisis sidik ragam, jenis ransum yang digunakan dan variasi umur tidak berpengaruh signifikan terhadap kualitas eksternal seperti pada berat telur dan tebal kerabang. Nilai tebal kerabang berkisar antara 0,42-0,44 mm. Kualitas interior telur secara signifikan dipengaruhi oleh kelompok umur yang berbeda untuk warna yolk dan terdapat perbedaan signifikan jenis ransum terhadap viskositas telur.

Kata kunci : Produksi telur; Berat telur; Viskositas telur; Warna Yolk. 


\section{PENDAHULUAN}

Tingkat permintaan masyarakat terhadap komoditi berbasis hasil peternakan seperti susu, daging, dan telur terus mengalami peningkatan. Fenomena ini linier dengan semakin bertambahnya populasi manusia, edukasi yang semakin baik, tingkat awareness masyarakat terhadap gizi yang semakin tinggi serta semakin dalamnya pengetahuan masyarakat terkait esensi dan peranan nutrisi pangan, khususnya nutrisi esensial seperti protein. Faktor pendukung yang tak kalah pentingnya adalah daya beli masyarakat terhadap pangan berbasis protein juga semakin baik. Pemenuhan kebutuhan protein ini, salah satunya bisa disuplai oleh sektor peternakan yang memainkan peran yang sangat vital dalam memenuhi permintaan tersebut. Muara dari mata rantai pemenuhan protein bagi masyarakat berefek positif terhadap peningkatan dan perbaikan gizi masyarakat serta membawa pengaruh positif yang sangat signifikan bagi petani dan peternak dengan meningkatnya pendapatan dan kesejahteraan mereka (Berkhoff et al., 2020).

Subsektor peternakan yang dapat berperan sebagai supplier protein masyarakat adalah ayam petelur. Terdapat kontribusi yang sangat besar dari upaya ini dalam pemenuhan protein hewani masyarakat Indonesia. Harga telur yang relatif terjangkau oleh seluruh lapisan masyarkat, menjadikan komoditi pangan ini menjadi menu yang selalu ada dalam hidangan masyarakat dengan berbagai tingkat pendapatan. Selain itu, layer atau ayam petelur adalah salah satu varian ayam yang sangat baik dalam memproduksi telur, sehingga ternak ini memiliki keunggulan dan prospek yang sangat baik untuk dipelihara dan dikembangkan karena selain gampang diternakkan, waktu untuk berproduksi cepat dan tingkat produksi serta masa atau rentang produksinya berlangsung cukup panjang. Layer atau ayam petelur merupakan jenis ayam yang sangat efektif dalam memproduksi telur fase masa bertelur dimulai pada umur \pm 5 bulan dengan total jumlah produksi telur per ekor berkisar antara 260 - 310 butir tiap tahun (Zhang et al., 2020).

Bermacam manfaat dapat diperoleh dari komposisi telur, protein yang tinggi, sebagai nutrisi penting merupakan benefit utama yang membuat telur menjadi primadona, harga terjangkau dan multiutilitas telur selain untuk konsumsi langsung seperti untuk pembuatan roti, kue dan kosmetik adalah benefit lain dari telur. Kandungan nutrisi dalam sebutir telur terdiri dari; karbohidrat $0,9 \%$, lemak $11,2 \%$, protein $12,9 \%$, dan air $73,7 \%$, serta nyaris tidak terdapat kandungan lemak pada putih telur. Sementara mayoritas lemak telur disimpan dalam yolk dengan persentase sekitar $32 \%$, sedangkan putih telur hanya mengandung sedikit saja komposisi lemak. Timbunan lemak pada kedua bagian telur dipengaruhi oleh faktor genetik dan ransum yang dikonsumsi oleh ayam (Mattioli et al., 2020).

Dalam penyusunan ransum unggas, jagung mengambil porsi yang cukup besar. Jagung memiliki beberapa karakteristik antara lain; mengandung $33 \mathrm{mg} / \mathrm{kg}$ beta karoten, protein kasar (PK) 8,6\%, dan energi metabolisme (EM) $3370 \mathrm{kkal} / \mathrm{g}$. Karena kandungan protein jagung yang masih relatif rendah dibandingkan dengan tingkat kebutuhan unggas, maka jagung harus dicampur dengan konsentrat atau ransum yang mengandung protein yang tinggi (Marume et al., 2020).

Fungsi protein dan energi dalam ransum sangat esensial bagi unggas. Kekurangan kedua substansi ini tidak hanya mengganggu pertumbuhan unggas, tetapi juga dapat menurunkan produksi dan kualitas telur. Sehingga keseimbangan pemberian protein dan energi harus mendapatkan perhatian khusus dalam penyusunan ransum unggas.

Kualitas telur dikelompokkan ke dalam 2 kategori, yakni kualitas eksternal dan kualitas internal. Untuk memproduksi telur dengan kualitas yang baik, pemberian ransum yang sesuai dengan proporsi protein dan energi yang dibutuhkan penting untuk dilakukan (Moran et al., 2019).

Bertolak dari persoalan tersebut maka dilakukan penelitian efek penggunaan protein dan energi ransum yang bervariasi pada beberapa kelompok usia layer terhadap kualitas telur. Studi ini bermaksud untuk mengelaborasi kualitas telur yang diproduksi oleh layer pada beberapa tingkatan umur dengan komposisi ransum yang berbeda. 


\section{METODE PENELITIAN}

Penelitian ini dilaksanakan di Bulan Agustus hingga September 2017. Penelitian dilaksanakan di Puncak Mario, Kabupaten Sidenreng Rappang, Sulawesi Selatan.

\section{Materi Penelitian}

Alat dan Bahan

Alat-alat yang digunakan pada penelitian ini yaitu jangka sorong untuk mengukur ketebalan kerabang telur dan neraca digital dengan kepekaan 0,001 g untuk menimbang telur. Untuk menimbang ransum digunakan neraca jarum berskala dengan kepekaan $0,1 \mathrm{~g}$, tempat ransum, tempat minum, ember, alat kebersihan, piring, dan plastik.

Materi yang digunakan dalam penelitian ini adalah 45 ekor ayam petelur, untuk mengamati kualitas telur, 45 butir, ransum unggas, air minum dan kandang.

Ransum

Komposisi formulasi ransum unggas yang digunakan yaitu; konsentrat, jagung, bekatul dan air dengan takaran perbandingan seperti terlihat pada Tabel 1. Sedangkan umur produksi diilustrasikan dalam Tabel 2 dan denah rancangan penelitian digambarkan dalam Tabel 3.

Tabel 1. Komposisi Ransum yang diberikan

\begin{tabular}{ccccc} 
& & & Proporsi (\%) \\
No & Komposisi & I & II & III \\
\cline { 3 - 5 } & & 35 & 33 & 32 \\
\hline 1 & Kosentrat & 50 & 45 & 42 \\
2 & Jagung & 15 & 22 & 26 \\
\hline 3 & Bekatul & 100 & 100 & 100 \\
\hline
\end{tabular}

Tabel 2. Umur Produksi Ayam

\begin{tabular}{cc} 
No. & Umur Produksi Ayam (minggu) \\
\hline A & $18-29$ \\
B & $30-49$ \\
C & $50-$ afkir \\
\hline
\end{tabular}

Tabel 3. Desain Penelitian

\begin{tabular}{ccccc}
\hline \multirow{2}{*}{ Umur Ayam } & \multicolumn{3}{c}{ Treatment } & Total \\
\cline { 2 - 4 } & $\begin{array}{c}\text { Ransum I }(18,1 \% \\
\text { protein })\end{array}$ & $\begin{array}{c}\text { Ransum II } \\
(18,7 \% \\
\text { protein })\end{array}$ & $\begin{array}{c}\text { Ransum III (17,4\% } \\
\text { protein) }\end{array}$ & kelompok \\
\hline A & AI & A II & A III & 15 \\
B & B I & B II & B III & 15 \\
C & C I & C II & C III & 15 \\
\hline $\begin{array}{c}\text { Total rata-rata } \\
\text { perlakuan }\end{array}$ & 15 & 15 & 15 & 45 \\
\hline
\end{tabular}

\section{Desain dan Alur Penelitian}

Prosedur yang digunakan dalam penelitian yaitu:

1. Desain penelitian

Model rancangan penelitian yang diaplikasikan adalah Rancangan Acak Kelompok (RAK). Terdapat 3 treatment jenis ransum serta 3 variasi umur ayam yang direplikasi sebanyak 3 kali terhadap karakteristik telur.

2. Formulasi ransum untuk ayam petelur

Komposisi ransum yang digunakan pada ayam petelur berupa bekatul, konsentrat dan 
jagung dengan proporsi yang variasinya secara rinci tergambar dalam Tabel 3.

Variabel Penelitian

Variabel yang diobservasi pada penelitian ini adalah karakteristik telur, dengan indikator sebagai berikut:

a. Kualitas eksternal yang meliputi

kerabang dan berat telur.

b. Kualitas internal yang meliputi warna yolk dan viskositas telur.

Analisis Data

Analisis statistik terhadap data yang telah diperoleh menggunakan model sidik ragam menggunakan pola Rancangan Acak Kelompok (RAK) untuk mendeteksi signifikansi perlakuan terhadap parameter yang diukur. Jika terdapat efek yang nyata, lalu diteruskan dengan melakukan uji Beda Nyata Terkecil (BNT) (Adinugraha \& Wijayaningrum, 2004). Analisis-analisis tersebut dijalankankan dengan memanfaatkan fasilitas software SPSS versi 16.

\section{HASIL DAN PEMBAHASAN}

\section{Kualitas eksternal Telur}

Tebal Kerabang Telur

Efek pemanfaatan tiga (3) jenis ransum yang bervariasi komposisinya terhadap nilai ketebalan kerabang $(\mathrm{mm})$ telur ayam Lohman pada kelompok umur ayam yang berbeda diilustrasikan dalam Tabel 4.

Tabel 4. Efek Jenis Ransum pada Ketebalan Kerabang Telur (milimeter) Ayam Lohman Pada Kelompok Umur Ayam yang Berbeda.

\begin{tabular}{|c|c|c|c|c|c|c|c|c|c|}
\hline & \multicolumn{3}{|c|}{ Ransum I } & \multicolumn{3}{|c|}{ Ransum II } & \multicolumn{3}{|c|}{ Ransum III } \\
\hline & $\begin{array}{c}\text { Umur } \\
\text { Ayam } \\
\text { A } \\
\end{array}$ & $\begin{array}{c}\text { Umur } \\
\text { Ayam } \\
\text { B } \\
\end{array}$ & $\begin{array}{c}\text { Umur } \\
\text { Ayam } \\
\mathrm{C} \\
\end{array}$ & $\begin{array}{c}\text { Umur } \\
\text { Ayam } \\
\text { A } \\
\end{array}$ & $\begin{array}{c}\text { Umur } \\
\text { Ayam } \\
\text { B } \\
\end{array}$ & $\begin{array}{c}\text { Umur } \\
\text { Ayam } \\
\mathrm{C} \\
\end{array}$ & $\begin{array}{c}\text { Umur } \\
\text { Ayam } \\
\text { A }\end{array}$ & $\begin{array}{c}\text { Umur } \\
\text { Ayam } \\
\text { B } \\
\end{array}$ & $\begin{array}{c}\text { Umur } \\
\text { Ayam } \\
\mathrm{C} \\
\end{array}$ \\
\hline & 0.42 & 0.42 & 0.43 & 0.43 & 0.44 & 0.43 & 0.42 & 0.43 & 0.44 \\
\hline & 0.43 & 0.43 & 0.44 & 0.43 & 0.43 & 0.44 & 0.43 & 0.43 & 0.44 \\
\hline & 0.42 & 0.43 & 0.44 & 0.42 & 0.43 & 0.44 & 0.42 & 0.43 & 0.44 \\
\hline & 0.42 & 0.42 & 0.42 & 0.42 & 0.42 & 0.43 & 0.43 & 0.44 & 0.43 \\
\hline & 0.42 & 0.43 & 0.44 & 0.42 & 0.43 & 0.44 & 0.42 & 0.43 & 0.44 \\
\hline Total & 2.11 & 2.13 & 2.17 & 2.12 & 2.15 & 2.18 & 2.12 & 2.16 & 2.19 \\
\hline $\begin{array}{l}\text { Rata- } \\
\text { Rata }\end{array}$ & $0.42^{\mathrm{ns}}$ & $0.43^{\text {ns }}$ & $0.43^{\mathrm{ns}}$ & $0.42^{\mathrm{ns}}$ & $0.43^{\text {ns }}$ & $0.44^{\mathrm{ns}}$ & $0.42^{\mathrm{ns}}$ & $0.43^{\text {ns }}$ & $0.44^{\mathrm{ns}}$ \\
\hline
\end{tabular}

Keterangan: ${ }^{\mathrm{ns}}=$ Non Significant.

Sumber: Hasil Penelitian, 2017.

Hasil analisis sidik ragam tampak bahwa tidak terdapat efek signifikan jenis ransum dan kelompok umur ayam yang berbeda pada nilai ketebalan kerabang telur ayam Lohman. Ratarata nilai ketebalan kerabang telur hasil penelitian yang diperoleh berada pada rentang $0,42-0,44 \mathrm{~mm}$. Secara numerik, nilai ketebalan kerabang telur yang dihasilkan pada penelitian ini dapat dikategorikan ke dalam kerabang telur yang tebal. Hal ini sejalan dengan pendapat yang mengatakan bahwa nilai ketebalan kerabang telur yang berada pada rentang $0,33-0,35 \mathrm{~mm}$ dapat dikategorikan sebagai kerabang telur yang baik. Kondisi ini juga dipengaruhi oleh konsumsi fosfor dan kalsium dan umur ayam saat berproduksi (Mattioli et al., 2020).
Faktor dominan dalam aktifitas sintesis kerabang telur dalam uterus unggas yakni kandungan unsur fosfor $(\mathrm{P})$ dan kalsium $(\mathrm{Ca})$ di dalam ransum, ini sesuai dengan pernyataan (Suprapto et al., 2012) yang menggarisbawahi bahwa, konsumsi unggas terhadap unsur kalsium (Ca) yang sesuai kebutuhan akan membantu proses sitesis kerabang telur yang baik, memperbaiki struktur dan ketebalan kerabang telur, komposisi dan proporsi $\mathrm{Ca}$ dan $\mathrm{P}$ dalam ransum memiliki peran yang sangat vital dalam pembentukan kerabang telur yang berkualitas karena pada proses sintesis struktur kerabang telur ion-ion karbonat dan ion-ion $\mathrm{Ca}$ menjadi sangat esensial keberadaannya di dalam ransum. 
Absorbsi kalsium yang terdapat di dalam ransum sangat berperan dalam menentukan kualitas kerabang telur, hal ini juga akan mempengaruhi ketebalan dan struktur dari kerabang telur. Upaya peningkatan ketebalan kerabang telur dapat dilakukan melalui penambahan proporsi kalsium (Ca) dalam ransum, penurunan kualitas dan ketebalan kerabang telur berbanding terbalik dengan pertambahan umur ayam, dan dipengaruhi oleh faktor genetik dan komposisi ransum khususnya keseimbangan unsur $\mathrm{Ca}$ dan $\mathrm{P}$.
Terdapat dua (2) bagian utama yaitu kerabang yang memiliki ketebalan sangat kecil (tipis) dalam bentuk membran disintesis di isthmus serta lapisan yang agak tebal dan keras disintesis di uterus (Necidová et al., 2019).

Berat Telur

Efek pemanfaatan tiga (3) jenis ransum yang bervariasi komposisinya terhadap berat telur ayam lohman pada kelompok umur ayam yang berbeda tergambar dalam Tabel 5 .

Tabel 5. Efek Jenis Ransum pada Berat Telur (gram) Ayam Lohman Pada Kelompok Umur Ayam yang Berbeda.

\begin{tabular}{|c|c|c|c|c|c|c|c|c|c|}
\hline & \multicolumn{3}{|c|}{ Ransum I } & \multicolumn{3}{|c|}{ Ransum II } & \multicolumn{3}{|c|}{ Ransum III } \\
\hline & $\begin{array}{c}\text { Umur } \\
\text { Ayam } \\
\text { A }\end{array}$ & $\begin{array}{c}\text { Umur } \\
\text { Ayam } \\
\text { B }\end{array}$ & $\begin{array}{c}\text { Umur } \\
\text { Ayam } \\
\text { C }\end{array}$ & $\begin{array}{c}\text { Umur } \\
\text { Ayam } \\
\text { A }\end{array}$ & $\begin{array}{c}\text { Umur } \\
\text { Ayam } \\
\text { B } \\
\end{array}$ & $\begin{array}{c}\text { Umur } \\
\text { Ayam } \\
\text { C }\end{array}$ & $\begin{array}{c}\text { Umur } \\
\text { Ayam } \\
\text { A }\end{array}$ & $\begin{array}{c}\text { Umur } \\
\text { Ayam } \\
\text { B }\end{array}$ & $\begin{array}{c}\text { Umur } \\
\text { Ayam } \\
\text { C }\end{array}$ \\
\hline & 55 & 60 & 55 & 60 & 65 & 70 & 65 & 70 & 65 \\
\hline & 65 & 65 & 55 & 65 & 65 & 60 & 65 & 65 & 60 \\
\hline & 60 & 60 & 60 & 65 & 55 & 65 & 60 & 65 & 65 \\
\hline & 50 & 50 & 65 & 65 & 65 & 50 & 60 & 60 & 55 \\
\hline & 65 & 65 & 65 & 50 & 55 & 65 & 65 & 55 & 70 \\
\hline Total & 295 & 300 & 300 & 305 & 305 & 310 & 315 & 315 & 315 \\
\hline $\begin{array}{c}\text { Rata- } \\
\text { Rata }\end{array}$ & $59^{\text {ns }}$ & $60^{\mathrm{ns}}$ & $60^{\mathrm{ns}}$ & $61^{\mathrm{ns}}$ & $61^{\mathrm{ns}}$ & $62^{\mathrm{ns}}$ & $63^{\mathrm{ns}}$ & $63^{\mathrm{ns}}$ & $63^{\mathrm{ns}}$ \\
\hline
\end{tabular}

Keterangan: ${ }^{\text {ns }}=$ Non significant.

Sumber: Hasil Penelitian, 2017

Tergambar dalam Tabel 5 bahwa terdapat kecenderungan perbedaan nilai berat telur ayam Lohman pada tingkat kelompok umur ayam yang berbeda, apabila umur ayam semakin bertambah tua, maka telur yang dihasilkan cenderung menjadi lebih besar. Meskipun demikian tidak terdapat perbedaan yang sginifikan jenis ransum dan kelompok umur terhadap berat telur ayam Lohman. Kemungkinan fenomena ini di sebabkan oleh beragamnya variasi umur ayam yang digunakan dalam penelitian ini. Hal ini sesuai dengan (Necidová et al., 2019) mengemukakan bahwa massa atau berat telur ayam sangat ditentukan oleh bangsa ayam, nutrisi berupa protein dalam ransum, serta umur ayam. Kualitas telur juga dipengaruhi yang digunakan juga sangat dipengaruhi oleh lama simpan telur sebagaimana dilaporkan oleh (Kamaruddin et al., 2020).

Komposisi atau kandungan nutrisi yang terdapat dalam ransum seperti protein, asam amino spesifik seperti methionine dan lysine, energi, lemak total, dan asam lemak esensial seperti asam linoleat memiliki pengaruh yang kuat terhadap proses pembentukan telur khususnya pada berat dan volume (ukuran telur). Jika dalam proses asupan nutrisi pada ayam terdapat kekurangan suplai pada salah satu nutrisi tersebut, maka akan menurunkan massa atau bobot telur. Jika hal ini berlangsung pada masa produksi ayam sebelum mencapai umur 40 minggu, akan berefek pada berkurangnya persentase produksi telur. Bobot telur juga tidak dapat dipisahkan dari peran massa atau bobot yolk, dimana proporsi yolk terhadap total massa telur sekitar 30--32\%. Bobot yolk juga ditentukan oleh status dan perkembangan organ reproduksi betina unggas (ovarium). Sebagai tempat sintesis yolk, ukuran ovarium yang kurang sempurna akan memproduksi yolk dengan bobot yang kecil. Faktorlain yang ikut memainkan peran penting dalam proses sintesis ini adalah efektivitas penyerapan nutrisi yang ada di dalam yang diberikan kepada unggas (Ipek \& Sozcu, 2017). 
Kualitas Interior Telur

Warna Yolk

Efek dari penggunaan tiga (3) jenis ransum yang bervariasi komposisinya terhadap warna yolk ayam Lohman pada kelompok umur ayam yang berbeda tergambar dalam Tabel 6

Tabel 6. Efek Jenis Ransum pada Warna Yolk Telur Ayam Lohman Pada Kelompok Umur Ayam yang Berbeda.

\begin{tabular}{ccccccccc}
\hline & Ransum I & & \multicolumn{3}{c}{ Ransum II } & \multicolumn{3}{c}{ Ransum III } \\
\hline Umur & Umur & Umur & Umur & Umur & Umur & Umur & Umur & Umur \\
Ayam & Ayam & Ayam & Ayam & Ayam & Ayam & Ayam & Ayam & Ayam \\
$\mathrm{A}$ & $\mathrm{B}$ & $\mathrm{C}$ & $\mathrm{A}$ & $\mathrm{B}$ & $\mathrm{C}$ & $\mathrm{A}$ & $\mathrm{B}$ & $\mathrm{C}$ \\
\hline $\mathrm{K}$ & $\mathrm{P}$ & $\mathrm{P}$ & $\mathrm{K}$ & $\mathrm{P}$ & $\mathrm{P}$ & $\mathrm{K}$ & $\mathrm{P}$ & $\mathrm{P}$ \\
$\mathrm{K}$ & $\mathrm{K}$ & $\mathrm{P}$ & $\mathrm{P}$ & $\mathrm{K}$ & $\mathrm{P}$ & $\mathrm{K}$ & $\mathrm{K}$ & $\mathrm{P}$ \\
$\mathrm{K}$ & $\mathrm{P}$ & $\mathrm{K}$ & $\mathrm{P}$ & $\mathrm{P}$ & $\mathrm{K}$ & $\mathrm{P}$ & $\mathrm{K}$ & $\mathrm{P}$ \\
$\mathrm{P}$ & $\mathrm{K}$ & $\mathrm{K}$ & $\mathrm{K}$ & $\mathrm{K}$ & $\mathrm{P}$ & $\mathrm{P}$ & $\mathrm{P}$ & $\mathrm{K}$ \\
$\mathrm{K}$ & $\mathrm{K}$ & $\mathrm{P}$ & $\mathrm{K}$ & $\mathrm{K}$ & $\mathrm{P}$ & $\mathrm{P}$ & $\mathrm{K}$ & $\mathrm{P}$ \\
\hline
\end{tabular}

Keterangan: $\mathrm{K}=$ Kuning; $\mathrm{P}=$ Pucat.

Sumber: Hasil Penelitian, 2017.

Dari hasil analisis sidik ragam yang telah dilakukan terlihat tidak terdapat efek yang signifikan pada warna yolk yang disebabkan oleh variasi atau perbedaan komposisi ransum yang diberikan pada beberapa kelompok ayam yang mempunyai umur yang berbeda pula. Meskipun dalam Tabel 6 menunjukkan bahwa pemberian ransum yang berbeda pada kelompok umur ayam yang berbeda terdapat kecenderung dominasi warna kuning pada kelompok umur 18 sampai 29 minggu dan umur 30-49 minggu, dan warna pucat pada kelompok umur 50-afkir.

Perubahan warna yolk yang diperoleh dalam penelitian kemungkinan dipengaruhi oleh umur ayam yang digunakan dan kandungan pigmen xantofill pada penyusun ransum (jagung), perbedaan level penambahan proporsi jagung dalam ransum akan ikut mempengaruhi warna yolk. Umur ayam yang semakin menua akan menurunkan kemampuan saluran pencernaan dalam melakukan penyerapan nutrisi yang terdapat dalam ransum dan berakibat pada kualitas produksi telur yang dihasilkan. Xanthofil adalah unsur yang mampu mempengaruhi proses pigmentasi atau aktifitas pewarnaan pada yolk. Pigmen ini secara fisiologis dalam organ pencernaan unggas akan diserap dari ransum yang diberikan dan didistribusikan kepada bagian tubuh atau organ-organ unggas yang membutuhkannya (Liu et al., 2020).
Viskositas Telur

Berdasarkan hasil analisis sidik ragam tampak bahwa jenis ransum yang digunakan dan kelompok umur ayam yang berbeda tidak terdapat adanya efek yang nyata terhadap niali kekentalan atau viskositas telur ayam Lohman. Jika ditinjau berdasarkan perbedaan jenis atau kelompok ransum yang digunakan, terlihat bahwa ransum I, ransum II dan ransum III memiliki efek yang signifikan terhadap nilai kekentalan atau viskositas telur. Efek perbedaan jenis atau kelompok ransum yang digunakan pada nilai kekentalan atau viskositas telur ayam Lohman pada kelompok umur ayam yang berbeda tergambar dalam Tabel 7 .

Proporsi kandungan protein yang terdapat dalam ransum ayam petelur sangat berpengaruh terhadap kekentalan telur. Dari hasil penelitian seperti terlihat pada Tabel 7, Perbedaan komposisi ransum belum menunjukkan adanya efek yang nyata terhadap kekentalan telur. Hal yang sama terjadi pada kelompok umur ayam yang tak menunjukkan efek yang signifikan pada viskositas atau kekentalan telur. Salah satu karakteristik yang mencerminkan kualitas telur adalah nilai kekentalan telur yang tinggi. Dan, proporsi protein dalam ransum menjadi faktor penentu dalam meningkatkan viskositas telur yang merefleksikan kualitas internal telur, jika kandungan protein dalam ransum tinggi akan bermuara pada bertambahnya nilai kekentalan pada telur. Hal ini di dukung oleh (Liu et al., 
2020) menyatakan bahwa kekentalan atau viskositas telur dipengaruhi oleh kandungan protein yang terdapat dalam ransum yang diberikan kepada ternak unggas.

Tabel 7. Efek Jenis Ransum Terhadap Viskositas Telur Ayam Lohman Pada Kelompok Umur Ayam yang Berbeda.

\begin{tabular}{ccccccccc}
\hline & Ransum I & & \multicolumn{3}{c}{ Ransum II } & \multicolumn{3}{c}{ Ransum III } \\
\hline Umur & Umur & \multirow{2}{*}{ Umur } & Umur & Umur & Umur & Umur & Umur & Umur \\
Ayam & Ayam & Ayam C & Ayam & Ayam & Ayam & Ayam & Ayam & Ayam \\
$\mathrm{A}$ & $\mathrm{B}$ & $\mathrm{A}$ & $\mathrm{B}$ & $\mathrm{C}$ & $\mathrm{A}$ & $\mathrm{B}$ & $\mathrm{C}$ \\
\hline $\mathrm{k}$ & $\mathrm{k}$ & $\mathrm{k}$ & $\mathrm{e}$ & $\mathrm{k}$ & $\mathrm{k}$ & $\mathrm{k}$ & $\mathrm{e}$ & $\mathrm{e}$ \\
$\mathrm{e}$ & $\mathrm{k}$ & $\mathrm{e}$ & $\mathrm{k}$ & $\mathrm{e}$ & $\mathrm{k}$ & $\mathrm{e}$ & $\mathrm{k}$ & $\mathrm{k}$ \\
$\mathrm{k}$ & $\mathrm{k}$ & $\mathrm{e}$ & $\mathrm{e}$ & $\mathrm{k}$ & $\mathrm{e}$ & $\mathrm{k}$ & $\mathrm{e}$ & $\mathrm{e}$ \\
$\mathrm{k}$ & $\mathrm{e}$ & $\mathrm{e}$ & $\mathrm{e}$ & $\mathrm{e}$ & $\mathrm{e}$ & $\mathrm{e}$ & $\mathrm{k}$ & $\mathrm{k}$ \\
$\mathrm{e}$ & $\mathrm{k}$ & $\mathrm{e}$ & $\mathrm{k}$ & $\mathrm{e}$ & $\mathrm{e}$ & $\mathrm{e}$ & $\mathrm{k}$ & $\mathrm{e}$ \\
\hline
\end{tabular}

Keterangan: $\mathrm{k}=$ kental; $\mathrm{e}=$ encer.

Sumber: Hasil Penelitian, 2017.

\section{KESIMPULAN DAN SARAN}

Kesimpulan

Dari uraian temuan (hasil) dan diskusi dalam pembahasan yang telah diuraikan, kesimpulan yang dapat diambil adalah bahwa pemakaian tiga (3) jenis ransum dan kelompok umur layer yang berbeda tidak menunjukkan efek yang signifikan pada kualitas eksternal telur maupun terhadap kualitas internal telur. Warna yolk cenderung kuning pada kelompok umur A dan B. Sementara nilai ketebalan kerabang telur berada pada kisaran antara 0,42 $-0,44 \mathrm{~mm}$.

Pemberian ransum dengan komposisi yang berbeda tidak berpengaruh signifikan pada massa atau berat telur yang diproduksi, meskipun massa atau berat telur terlihat memiliki tren yang berbeda pada setiap kelompok ransum yang diberikan, ransum 3 cenderung lebih tinggi.

Saran

Untuk memperoleh hasil perbedaan pengaruh jenis ransum lebih komprehensif, sebaiknya penelitian dengan menggunakan materi penelitian dengan umur ayam yang seragam.

\section{DAFTAR PUSTAKA}

Adinugraha B. S. dan Wijayaningrum T. N. 2004. Rancangan Acak Lengkap Dan Rancangan Acak Kelompok Pada Bibit Ikan. Seminar Nasional UMS, 47-56.

Berkhoff J. Alvarado-Gilis C. Keim J. P.
Alcalde J. A. Vargas-Bello-Pérez E. and Gandarillas M. 2020. Consumer preferences and sensory characteristics of eggs from family farms. Poultry Science. https://doi.org/10.1016/j.psj.2020.06.064

Ipek A. and Sozcu A. 2017. Comparison of hatching egg characteristics, embryo development, yolk absorption, hatch window, and hatchability of Pekin Duck eggs of different weights. Poultry Science, 96(10), 3593-3599. https://doi.org/10.3382/ps/pex181

Kamaruddin A. Monim H. Mulyadi M. dan Sambodo P. 2020. Kualitas Fisik Telur Ayam Petelur pada Tingkat Pelaku Usaha di Kabupaten Manokwari Provinsi Papua Barat. Jurnal Ilmu Peternakan Dan Veteriner Tropis (Journal of Tropical Animal and Veterinary Science), 10(2), 128.

https://doi.org/10.46549/jipvet.v10i2.111

Liu B. Zhou Q. Zhu J. Lin G. Yu D. and Ao, T. 2020. Time course of nutritional and functional property changes in egg yolk from laying hens fed docosahexaenoic acid-rich microalgae. Poultry Science, 99(9), 4616-4625. https://doi.org/10.1016/j.psj.2020.06.007

Marume U. Mokagane J. M. Shole C. O. and Hugo A. 2020. Citrullus lanatus essential oils inclusion in diets elicit nutraceutical effects on egg production, egg quality, and physiological characteristics in layer hens. Poultry Science, 99(6), 3038-3046. https://doi.org/10.1016/j.psj.2020.01.029 
Mattioli S. Ortenzi R. Scuota S. Cartoni Mancinelli A. Dal Bosco A. Cotozzolo E. and Castellini C. 2020. Impact of ozone and UV irradiation sanitation treatments on the survival of Salmonella and the physical-chemical characteristics of hen eggs. Journal of Applied Poultry Research, 29(2), 409-419. https://doi.org/10.1016/j.japr.2020.01.004

Moran C. A. Morlacchini M. Keegan J. D. and Fusconi G. 2019. Increasing the Omega-3 Content of Hen's Eggs Through Dietary Supplementation with Aurantiochytrium limacinum Microalgae: Effect of Inclusion Rate on the Temporal Pattern of Docosahexaenoic Acid Enrichment, Efficiency of Transfer, and Egg Characteristics. Journal of Applied Poultry Research, 28(2), 329-338. https://doi.org/10.3382/japr/pfy075

Necidová L. Bursová Š. Ježek F. Haruštiaková
D. Vorlová L. and Golian J. 2019. Effect of preservatives on the shelf-life and sensory characteristics of pasteurized liquid whole egg stored at $4^{\circ} \mathrm{C}$. Poultry Science, 98(11), 5940-5948. https://doi.org/10.3382/ps/pez378

Suprapto W. Kismiyati S. and Suprijatna E. 2012. ( the Use of Eggshell Meal in the Quails on Tibia and. Animal Agricultur Journal, 1(1), 75-90.

Zhang Y. N. Wang S. Huang X. B. Li K. C. Chen W. Ruan D. Xia W. G. Wang S. L. Abouelezz K. F. M. and Zheng C. T. 2020. Estimation of dietary manganese requirement for laying duck breeders: effects on productive and reproductive performance, egg quality, tibial characteristics, and serum biochemical and antioxidant indices. Poultry Science. https://doi.org/10.1016/j.psj.2020.06.076 